\title{
Chemistry and Ultrastructure of the Hyphal Walls of Pythium acanthicum
}

\author{
By J. H. SIETSMA \\ Botanical Laboratory, University of Groningen, Biologisch Centrum, \\ Haren, The Netherlands \\ AND J. J. CHILD, L. R. NESBITT AND R. H. HASKINS \\ Prairie Regional Laboratory, National Research Council, \\ Saskatoon, Saskatchewan $S_{7} N$ oW9, Canada
}

(Received 18 April 1974; revised 9 September 1974)

SUMMARY

Combined methylation, Smith degradation and enzymic studies show that the hyphal wall of Pythium consists predominantly of a (I,3)-linked $\beta$-D-glucan main chain substituted by a short chain at the 6-position of each third unit. Electron micrographs show that the hyphal wall has two different textures; the inner surface is distinctly microfibrillar while the outer surface is non-fibrillar. The microfibrils are covered with amorphous matrix material, partly soluble in aqueous $\mathrm{KOH}$ and almost completely removable by treatment with exo-laminaranase. This matrix material consists also of a branched $\beta$-D-glucan containing $(1,3)$ - and $(1,6)$-linkages. The microfibrils remaining after $(\mathrm{I}, 3)-\beta$-glucanase treatment are composed of a $\beta$-glucan with $(I, 4)$ - and $(I, 3)$-linked units that are occasionally substituted in the 6-positions.

\section{INTRODUCTION}

Previous studies have shown that the wall of Pythium consists chiefly of glucans $(80 \%, w / w)$, lipids $(8 \%, w / w)$, protein $(2 \%, w / w)$ and some sugars (Sietsma, Eveleigh \& Haskins, 1969). At least two different types of $\beta$-glucan have been recognized: cellulose, which is a minor component, and a branched $(\mathrm{I}, 3)-,(\mathrm{I}, 6)$-linked $\beta$-glucan, which is the major wall component. Several other workers have shown that hyphal walls of other Oomycetes have a similar chemical structure (Aronson, Cooper \& Fuller, 1967; Cooper \& Aronson, 1967; NovaesLedieu, Jimenez-Martinez \& Villanueva, I967; Bartnicki-Garcia, 1968). The present study investigates further the nature of the hyphal wall of Pythium acanthicum.

\section{METHODS}

Organism. Pythium acanthicum Drechsler (PRL2142) was used with the method of cultivation and the preparation of wall material as described by Sietsma et al. (1969).

Fractionation of the wall. The wall was further purified by extracting the lipids with a refluxing ether-chloroform mixture (I:I), and removing proteinaceous material by digesting with pronase $(500 \mu \mathrm{g} / \mathrm{ml}, \mathrm{pH} 8 \cdot 0$; Nutritional Biochemicals Corporation, Cleveland, Ohio, U.S.A.) at $35^{\circ} \mathrm{C}$ for $24 \mathrm{~h}$. After repeated washing, the cleaned and purified walls (fraction I) were freeze-dried and stored until required.

The $\mathrm{KOH}$-soluble fraction (fraction 2) was prepared by extracting the wall material 
twice by shaking with $\mathrm{M}-\mathrm{KOH}$ at $60^{\circ} \mathrm{C}$ for $20 \mathrm{~min}$. The extracted polysaccharides were precipitated by adding 2 vol. ethanol to the extract and were washed twice with ethanol and freeze-dried. The KOH-insoluble fraction (fraction 3) was the residue left over after $\mathrm{KOH}$ extraction. This was washed twice with water and freeze-dried. The residue remaining after $(I, 3)-\beta$-glucanase treatment of fraction $I$ material was obtained by incubating the wall suspension $(5 \mathrm{mg} / \mathrm{ml}$ in acetate buffer $\mathrm{pH} 5.8)$ with a mixture of endo- and exo-laminaranase (final concn of $\mathrm{I} \mathrm{mg} \mathrm{each} \mathrm{enzyme/ml} \mathrm{protein)} \mathrm{at} 35^{\circ} \mathrm{C}$ for $24 \mathrm{~h}$ with toluene as an inhibitor of bacterial growth. At the end of the incubation period the suspension was centrifuged at $10000 \mathrm{~g}$ for $10 \mathrm{~min}$, the precipitate washed three times with water and freeze-dried (fraction 4 ).

Substrates. The following substrates were used: Claviceps glucan, a $\beta$-glucan with a $(\mathrm{I}, 3)-$ linked main-chain substituted on the 6-position of each fourth unit by a single-unit side chain, isolated from a culture filtrate of Claviceps PRL 1980 as described by Perlin \& Taber (I963); laminaran, a $(\mathrm{I}, 3)$-linked $\beta$-glucan and nigeran, an $\alpha$-glucan with $(\mathrm{I}, 3)$ - and $(\mathrm{I}, 4)-$ linkages (Koch-Light Laboratories, Colnbrook, Buckinghamshire); carboxymethylcellulose (CM-cellulose; courtesy Hercules Trading Corp., Wilmington, Delaware, U.S.A.); pustulan, a $(\mathrm{I}, 6)$-linked $\beta$-glucan (Calbiochem); amylose (Sigma); xylan and polygalacturonic acid (Nutritional Biochemicals Corp.).

Enzymes. Streptomyces cellulase was prepared as described by Sietsma, Eveleigh \& Haskins (1968). Both the exo- and endo-laminaranase were isolated from the culture filtrates of the basidiomycete QM806 and Rhizopus QMI032, respectively, as described by Reese \& Mandels (1966). Both organisms were a gift from the U.S. Army Natick Laboratories, Massachusetts, U.S.A.

Glycosidase activity of the enzyme preparations was investigated by mixing enzyme solution $(0.5 \mathrm{ml}, 2 \mathrm{mg}$ protein $/ \mathrm{ml})$ with various polysaccharides $(5 \mathrm{mg} / \mathrm{ml}$ in $0.05 \mathrm{M}$-sodium acetate buffer $\mathrm{pH} 5.8 ; 0.5 \mathrm{ml}$ for $20 \mathrm{~h}$ at $35^{\circ} \mathrm{C}$ ). Toluene (2 drops) was added to prevent bacterial growth. The reactions were terminated by heating at $100^{\circ} \mathrm{C}$ for $10 \mathrm{~min}$. The degree of hydrolysis and the lytic products were characterized by paper chromatography (Whatman filter paper No. I ; solvent: ethyl acetate-acetic acid-water, 9:2:2, by vol.); reducing compounds were detected with $p$-anisidine hydrochloride.

The glycosidase enzymes were quantitatively tested with $0.5 \mathrm{ml}$ substrate $(5 \mathrm{mg} / \mathrm{ml} \mathrm{0.05} \mathrm{M-}$ sodium acetate buffer $\mathrm{pH} 5 \cdot 8)$ and enzyme to a final volume of $\mathrm{I} \cdot 0 \mathrm{ml}$, at $35^{\circ} \mathrm{C}$ for $\mathrm{IO} \mathrm{min}$. The enzyme preparations were diluted in order to get a maximum of $5 \%$ substrate degradation to maintain a stoichiometric response between the product and the amount of enzyme added. Reducing end-groups (as glucose equivalents) were estimated by the Nelson-Somogyi method (Nelson, 1944). An enzyme unit is defined as that amount of enzyme which releases I $\mu \mathrm{mol}$ glucose equivalent $/ \mathrm{min}$ at $35^{\circ} \mathrm{C}$.

The effects of the enzymes on the wall and fractions were tested by incubating $0.5 \mathrm{ml}$ of a wall suspension $(5 \mathrm{mg} / \mathrm{ml}$ in acetate buffer $\mathrm{pH} 5.8)$ with $0.5 \mathrm{ml}$ of an enzyme solution ( $2 \mathrm{mg}$ protein $/ \mathrm{ml}$ ) at $35^{\circ} \mathrm{C}$ for $20 \mathrm{~h}$ with toluene as bacterial inhibitor. The lytic products were characterized by paper chromatography and the degree of hydrolysis estimated from the difference between the total carbohydrate contents of the complete suspension and the total carbohydrate contents of the supernatant after sedimentation of the unhydrolysed part of the wall at $10000 \mathrm{~g}$ for Io min. The total carbohydrate was measured by the anthrone reaction (Ashwell, 1957).

Electron microscopy. Specimens, as suspensions in water, were placed on a Formvar-coated grid, dried at $40^{\circ} \mathrm{C}$ and shadowed in a Balzer coating unit with $\mathrm{Pt}-\mathrm{C}$ at an angle of $15^{\circ}$. The specimens were examined with a Zeiss EM9a electron microscope.

$X$-ray diffraction. Powder diagrams were made from complete hyphal walls and the three 
wall fractions. The samples were packed mechanically into small holes in plastic specimen discs. The packed discs were mounted on an X-ray collimator and exposed to nickel-filtered copper $(\mathrm{CuK} \alpha)$ radiation. The $\mathrm{X}$-ray tube was operated at $38 \mathrm{kV}, 23 \mathrm{~mA}$ and the exposure time was $30 \mathrm{~min}$. Specimen-to-film distance was $40 \mathrm{~cm}$.

Methylation-fragmentation analysis. The complete wall and the residue after $\mathrm{KOH}$ extraction were insoluble in dimethyl sulphoxide. Therefore a methylation procedure was applied as described by Zevenhuizen \& Bartnicki-Garcia (1969). The insoluble glucans were first partly methylated by the Haworth procedure (Hirst \& Percival, 1965) and became soluble in dimethyl sulphoxide. The methylation was then completed by applying the Hakomori procedure three times (Hakomori, 1964). The glucans soluble in dimethyl sulphoxide were directly methylated by the Hakomori procedure. The glucans were considered completely methylated when an infrared spectrum did not show any significant $\mathrm{OH}$ band absorption in the $3500 \mathrm{~cm}^{-1}$ region. The methylated polysaccharides were hydrolysed with sulphuric acid (Zevenhuizen \& Bartnicki-Garcia, 1969).

The methylated sugars were converted to the alditol acetates, separated and identified by gas-liquid chromatography (Bjorndal, Lindberg \& Svensson, 1967) using a Pye Unicam Model I04 gas chromatograph. Separations were made at a gas-flow rate of $40 \mathrm{ml}$ nitrogen per min on glass columns $(\mathrm{I} 600 \times 2 \mathrm{~mm})$ containing $3 \% \mathrm{OV}-225$ or $3 \%$ OS-138 (Becker Delft N.V., The Netherlands) on Chromosorb Q (100/120 mesh) at $180{ }^{\circ} \mathrm{C}$. Positive identification of the $O$-methyl glucitols was effected by comparison with authentic materials. These were obtained by sodium borohydride reduction of 2,3,4-tri- $O$-methyl-D-glucose (from dextran), 2,3,6-tri- $O$-methyl-D-glucose (from soluble starch), 2,4,6-tri- $O$-methyl-Dglucose (from laminaran), and 2,3,4-tri- $O$-methyl-D-glucose, 2,4,6-tri- $O$-methyl-D-glucose and 2,4-di-O-methyl-D-glucose (from Claviceps glucan). The polysaccharides were methylated by the Hakomori procedure and hydrolysed with acid.

Periodate oxidation. Periodate oxidation and Smith degradation of polysaccharides were performed as described by Hay, Lewis \& Smith (1965).

Chromatographic procedures. Paper and thin-layer chromatographic analyses were done on Whatman filter paper No. I and cellulose plates with the following solvent systems: $(a)$ $n$-butanol + ethanol + water ( $3: 1$ I I, by vol.); (b) ethyl acetate + pyridine + water (I0:4:3, by vol.); (c) ethyl acetate + acetic acid + water $(9: 2: 2$, by vol. $) ;(d)$ ethyl acetate + formic acid + acetic acid + water ( $18: 1: 3: 4$, by vol.). Reducing compounds were detected with $p$-anisidine and polyalcohols with metaperiodate-benzidine reagent.

\section{RESULTS}

\section{Characterization of the enzyme preparations}

Enzymes present in the three preparations used were surveyed by measuring the increase in reducing sugars in the reaction mixtures after incubation for $10 \mathrm{~min}$ with the substrate and by chromatographic analysis of the products after an incubation period of $20 \mathrm{~h}$. The results are presented in Table $\mathrm{I}$. Of particular interest is the trace amount of $(\mathrm{I}, 3)-\beta$-glucanase in Streptomyces cellulase, and pustulanase and cellulase activity in the endo-laminaranase preparation. It was confirmed that a combination of these three enzymes was able to produce protoplasts of Pythium (Eveleigh, Sietsma \& Haskins, 1968). No effort was made to remove the xylanase and polygalacturonase because previous studies have shown that neither hemicellulose nor pectin-like materials were components of the cell wall of Pythium (Cooper \& Aronson, 1967; Sietsma et al. 1969). 
Table I. Specificactivity of some enzyme preparations tested on several substrates

$\begin{array}{lccc}\text { Substrates } & \begin{array}{c}\text { Streptomyces } \\ \text { cellulase }\end{array} & \begin{array}{c}\text { Exo-laminaranase } \\ \text { (Basidiomycete QM806) }\end{array} & \begin{array}{c}\text { Endo-laminaranase } \\ \text { (Rhizopus QMio032) }\end{array} \\ \text { Claviceps glucan } & 0 & 0.02 \mathrm{I} & 0 \\ \text { Laminaran } & 0.013 & 4.8 & 0.360 \\ \text { Pustulan } & 0 & 0 & \operatorname{tr}^{*} \dagger \\ \text { CM-cellulose } & 0.458 & 0 & \operatorname{tr}^{*} \dagger \\ \text { Amylose } & 0 & 0 & 0 \\ \text { Nigeran } & 0 & 0 & 0 \\ \text { Xylan } & 0.002 & 0.005 \dagger & 0.142 \dagger \\ \text { Polygalacturonic acid } & 0.005 & 0.032 \dagger & 0.201 \dagger\end{array}$

* Trace amounts of activity were indicated when only small amounts of products were found on the chromatogram after $20 \mathrm{~h}$ incubation and no increase in reducing sugars was found after $10 \mathrm{~min}$ incubation.

$\dagger$ Endo-type activity, indicating that monosaccharides were not detected as hydrolysis products.

Table 2. Percentage anthrone-positive material in solution after $24 h$ treatment with enzymes

\begin{tabular}{|c|c|c|c|c|}
\hline Enzyme & $\begin{array}{c}\text { Wall } \\
\text { (fraction I) }\end{array}$ & $\begin{array}{c}\text { KOH-soluble } \\
\text { (fraction 2) }\end{array}$ & $\begin{array}{c}\text { KOH-insoluble } \\
\text { (fraction 3) }\end{array}$ & $\begin{array}{c}\text { Residue after } \\
\text { treatment with } \\
\beta(\mathrm{I}, 3)- \\
\text { glucanase } \\
\text { (fraction 4) }\end{array}$ \\
\hline Cellulase & Io & o & 25 & 48 \\
\hline Exo-laminaranase & 42 & 89 & 39 & 0 \\
\hline Endo-laminaranase & 78 & 100 & $6 r$ & 0 \\
\hline Exo-+ endo-laminaranase & 85 & 100 & 72 & 0 \\
\hline Exo- + endo-laminaranase + cellulase & 100 & 100 & 100 & 100 \\
\hline
\end{tabular}

Fractionation of the wall

The wall material obtained by mechanical separation and repeated washing of the mycelium (Sietsma et al. 1969) was purified by extracting the lipids with chloroform-ether and the protein removed by a digestion procedure with pronase. During these treatments no hexoses were liberated. The product obtained (fraction I) contained $98 \%$ of anthrone-positive material. This material was subjected to further treatment and fractionated. Fraction 2 contained material soluble in $\mathrm{M}-\mathrm{KOH}$ and precipitable with ethanol. This represented $12 \%$ of the total carbohydrate of the wall. It contained $98 \%$ of anthrone-positive material, was soluble in dimethyl sulphoxide, and the specific optical rotation $[\alpha]_{\mathrm{D}}^{25}=-9 \cdot 5^{\circ}$ in $\mathrm{M}-\mathrm{KOH}$ indicated that it contained mainly $\beta$-glucosidic linkages. Fraction 3 was insoluble in $\mathrm{M}-\mathrm{KOH}$. This was the residue from $\mathrm{KOH}$ extraction and constituted $88 \%$ of the total carbohydrate of the wall. It contained $100 \%$ of anthrone-positive material and was insoluble in dimethyl sulphoxide. Fraction 4 , the residue remaining after $(I, 3)$ - $\beta$-glucanase treatment of fraction $I$ material, represented I $5 \%$ of the total carbohydrate of the wall, contained $98 \%$ of anthronepositive material and was soluble in dimethyl sulphoxide.

\section{Effect of enzymes on the wall fractions}

The effect of the enzymes on the wall fractions is presented in Table 2. The $\mathrm{KOH}$-soluble fraction was almost completely solubilized by both laminaranases, indicating predominantly $\beta(\mathrm{I}, 3)$-linkages in this polysaccharide fraction. The $\mathrm{KOH}$-insoluble fraction was only partly solubilized by these enzymes. Fraction I was totally hydrolysed by combined cellulase and laminaranase. The residue remaining after treatment with a combination of exo- and endo- 
Table 3. Products of enzymic hydrolysis of wall fractions

\begin{tabular}{|c|c|c|c|}
\hline Enzyme & $\begin{array}{c}\text { Wall } \\
\text { (fraction I) }\end{array}$ & $\underset{\text { (fraction 2) }}{\mathrm{KOH} \text {-soluble }}$ & $\begin{array}{c}\text { KOH-insoluble } \\
\text { (fraction 3) }\end{array}$ \\
\hline Cellulase & $\left\{\begin{array}{l}\text { Cellobiose } \\
\text { Glucose }\end{array}\right.$ & & $\begin{array}{l}\text { Cellobiose } \\
\text { Glucose }\end{array}$ \\
\hline Exo-laminaranase & $\left\{\begin{array}{l}\text { Glucose } \\
\text { Gentiobiose }\end{array}\right.$ & $\begin{array}{l}\text { Glucose } \\
\text { Gentiobiose } \\
\text { Unknown (trace) }\end{array}$ & $\begin{array}{l}\text { Glucose } \\
\text { Gentiobiose }\end{array}$ \\
\hline Endo-laminaranase & $\left\{\begin{array}{l}\text { Laminaribiose } \\
\text { Laminaritriose } \\
\text { Oligosaccharides }\end{array}\right.$ & $\begin{array}{l}\text { Laminaribiose } \\
\text { Laminaritriose } \\
\text { Oligosaccharides }\end{array}$ & $\begin{array}{l}\text { Laminaribiose } \\
\text { Laminaritriose } \\
\text { Oligosaccharides }\end{array}$ \\
\hline
\end{tabular}

Table 4. O-methylethers of alditols obtained on methylation analysis of the wall of Pythium spp.

\begin{tabular}{|c|c|c|c|c|c|c|c|}
\hline \multirow[b]{2}{*}{ Sugar } & Retenti & $\begin{array}{l}\text { ion time } \\
\text { s) }\end{array}$ & wati of & mum & KOH- & $\underset{\text { insoluble* }}{\text { KOH- }}$ & \multirow{2}{*}{$\begin{array}{c}\text { Residue* } \\
\text { after } \beta(\mathrm{I}, 3) \\
\text { glucanase } \\
\text { treatment } \\
\text { (fraction 4) }\end{array}$} \\
\hline & OV-225 & OS-138 & linkage & (fraction I & 1) (fraction 2) & (fraction 3) & \\
\hline 2,3,4,6-tetra- $O$-Me-Glc & $1 \cdot \infty$ & $1 \cdot \infty$ & End-groups & 15 & 12 & 13 & 4 \\
\hline 2,4,6-tri-O-Me-Glc & $1 \cdot 83$ & I.77 & I,3 & 45 & 63 & 46 & $5 \mathrm{I}$ \\
\hline 2,3,6-tri-O-Me-Glc & $2 \cdot 27$ & I.89 & I, 4 & II & 2 & 17 & 35 \\
\hline 2,3,4-tri-O-Me-Glc & $2 \cdot 27$ & 1.99 & I,6 & 4 & 6 & 3 & 0 \\
\hline Unknown & 3.39 & $2 \cdot 80$ & & 8 & 4 & 7 & 3 \\
\hline 2,4-di-O-Me-Glc & 4.11 & $3 \cdot 49$ & $1,3,6$ & 17 & 13 & 12 & 5 \\
\hline
\end{tabular}

laminaranase was not solubilized by cellulase alone. The - synergistic action of all three enzymes was needed to hydrolyse this wall residue completely. The products of enzymic hydrolysis are shown in Table 3 .

\section{Methylation-fragmentation analysis}

Complete methylation analyses were carried out on the wall fractions. The methylated glucans (no significant $\mathrm{OH}$-band at $3500 \mathrm{~cm}^{-1}$ ) were hydrolysed and the products separated and identified by gas-liquid partition chromatography after conversion into their alditol acetates. Identification was effected by comparison with reference substances, obtained from methylated polysaccharides of known composition by hydrolysis followed by reduction. The results are given in Table 4. On a column packed with $\mathrm{OV}-225$ very close retention times were obtained for 2,3,6-tri- $O$-methyl-D-glucitol and 2,3,4-tri- $O$-methyl-D-glucitol. By using an OS-I38 column these substances were separated much better. The unidentified substance showed a retention time of $3.39 \mathrm{~s}$ on an OV-225 column, which is very close to the retention time of $3.38 \mathrm{~s}$ given for 2,6-di-O-methyl-D-glucitol by Longren \& Pilotti (197I). This could indicate a $3,4-\mathrm{D}-O$-substituted branching point providing that methylation was complete. Unfortunately no reference substances were available and this compound was not identified further.

\section{Electron microscopy}

Shadowed preparations of the complete wall showed a smooth outer surface and a fibrillar inner surface (Fig. $\mathrm{I} a$ ). Treatment of the wall with aqueous $\mathrm{KOH}$ caused part of the matrix material to disappear, and fibrils became visible (Fig. I $b$ ). Treatment with endo-laminaranase removed almost all of the matrix material and a loose network of fibrils was visible (Fig. Ic). At this stage the form of the hyphae was quite easily destroyed by short ultrasonic treatment. 
J. H. SIETSMA AND OTHERS
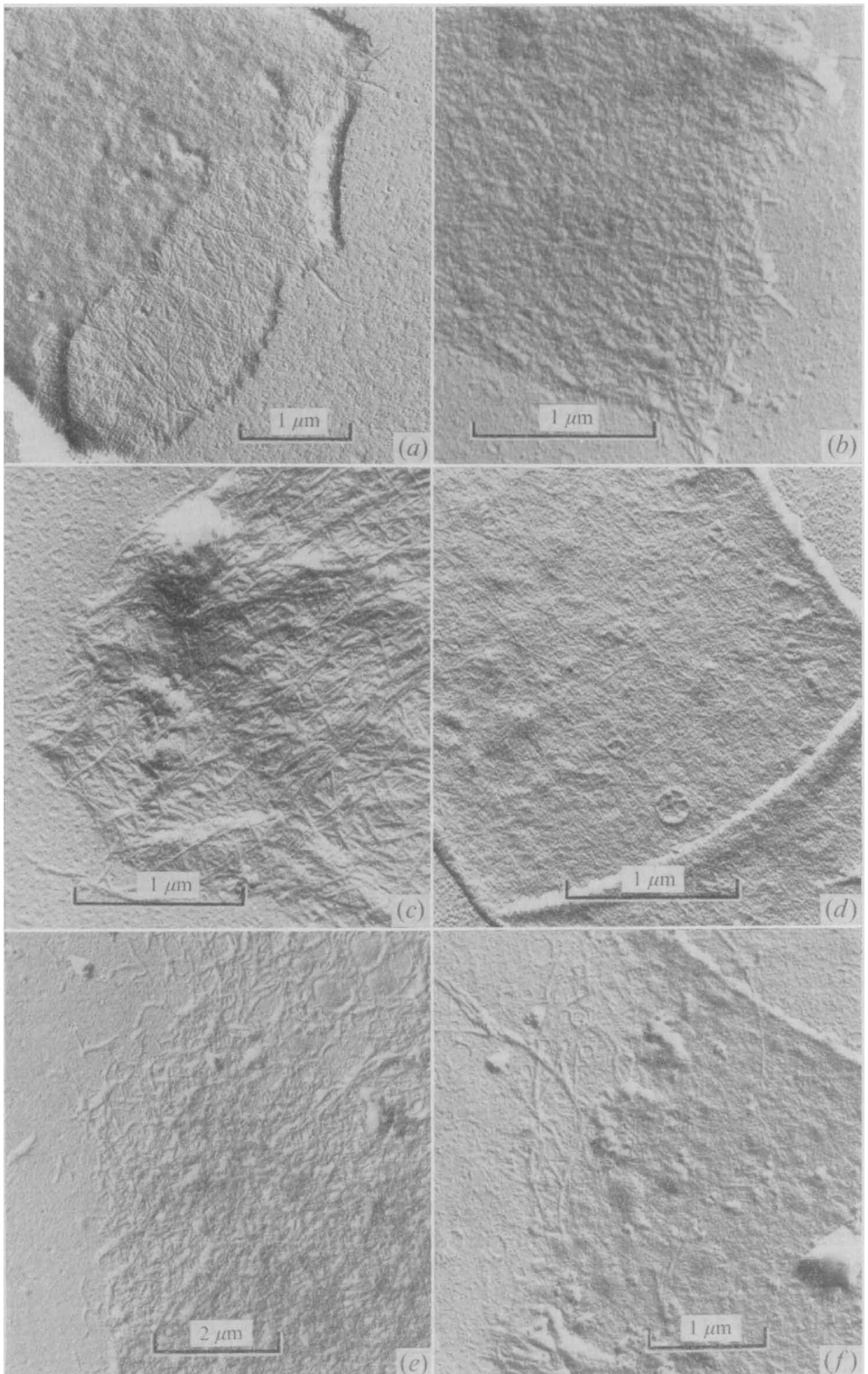


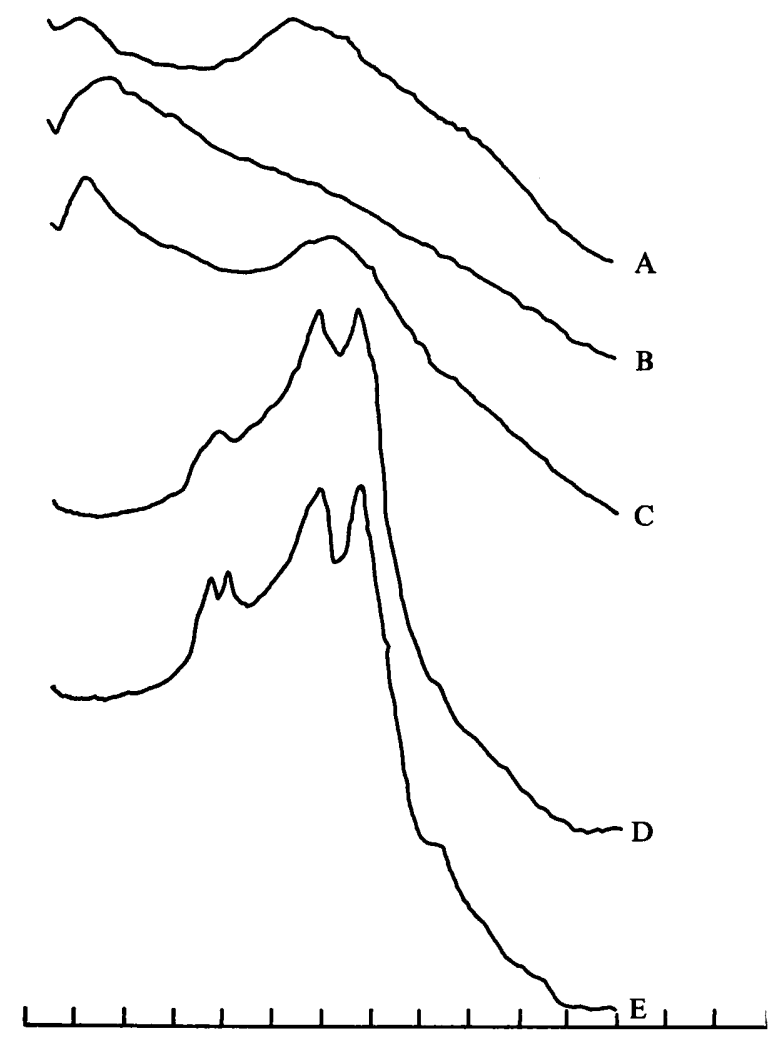

Fig. 2. Radial density tracings of X-ray powder diagrams of Pythium wall. A, untreated wall; $\mathrm{B}$, residue after $\beta(\mathrm{I}, 3)$-glucanase treatment; $\mathrm{C}, \mathrm{KOH}$-insoluble fraction; $\mathrm{D}$, same as $\mathrm{B}$ but treated 3 times with $\mathrm{H}_{2} \mathrm{O}_{2}$, acetic acid and boiling $\mathrm{HCl}$; E, filter paper.

The fibrils could be dissolved by a treatment with a combination of cellulase and exolaminaranase but not by either alone. Treatment of the wall with exo-laminaranase dissolved only part of the matrix material and the fibrils became very faintly visible through the surface (Fig. I $d$ ). Close observation indicated a slight orientation of the fibrils parallel to the axis of the hypha. Treatment with a combination of exo- and endo-laminaranase destroyed the shape of the hyphae and produced very short fibrils (Fig. I $e$ ). Cellulase treatment had little visible effect (Fig. I $f$ ) although some fibrils of the inner surface disappeared.

\section{$X$-ray diffraction studies}

None of the wall fractions showed an X-ray diffraction pattern. Even prolonged incubation with a combination of endo- and exo-laminaranase (which presented a fibrillar network under the electron microscope) did not give an X-ray diagram. This indicates that no crystalline material was present in the wall. Only repeated treatment of the walls with $\mathrm{H}_{2} \mathrm{O}_{2}$ and acetic acid, and boiling with mineral acid (Cooper \& Aronson, 1967) gave a pattern similar to cellulose I (Fig. 2).

Fig. I. Hyphal wall of Pythium acanthicum PRL2 I42. (a) A portion of the broken end of an empty hyphal tube. The granular texture corresponds to the outer surface and the fibrillar texture is the inner surface. (b) Residue of the wall after $\mathrm{KOH}$ extraction. (c) Wall after treatment with endolaminaranase. $(d)$ Wall after exo-laminaranase treatment. $(e)$ Wall digested with a combination of exo- and endo-laminaranase. $(f)$ Wall after treatment with cellulase. 


\section{Periodate oxidation}

In accordance with the structure inferred from enzymic hydrolysis, fractions 2 and 3 of the wall of Pythium consumed a considerable amount of periodate (fraction 2 consumed 0.40 $\mathrm{mol} / \mathrm{mol}$ anhydroglucose; fraction 3 consumed $0.48 \mathrm{~mol} / \mathrm{mol}$ anhydroglucose) with the release of formic acid $(0.18 \mathrm{~mol} / \mathrm{mol}$ anhydroglucose for fraction 2 and $0.15 \mathrm{~mol} / \mathrm{mol}$ anhydroglucose for fraction 3 ). If the latter arose mainly from oxidation of end-groups and (I,6)-linkages, consuming $2 \mathrm{~mol}$ periodate/mol formic acid released, then for the oxidation of $(\mathrm{I}, 4)$-linkages $0.04 \mathrm{~mol}$ periodate/mol anhydroglucose has been used in fraction 2 and $0.18 \mathrm{~mol}$ periodate $/ \mathrm{mol}$ anhydroglucose in fraction 3 . This indicates a structure of the two polysaccharides with a linkage ratio which is in close accordance with the results obtained with the methylation analysis (see Table 4), indicating that the methylation procedure was fairly complete. Reduction of the periodate-oxidized product with sodium borohydride followed by mild acid hydrolysis released mainly glycerol in fractions I and 2, and a trace of erythritol only in fraction 3 . The remaining glucans consumed very little periodate $(0.05 \mathrm{~mol} /$ mol anhydroglucose for fraction 2 and $0.03 \mathrm{~mol} / \mathrm{mol}$ anhydroglucose for fraction 3 ). Both glucans were completely hydrolysed by exo-laminaranase with glucose as sole product.

\section{DISCUSSION}

The results indicate that the hyphal wall of Pythium acanthicum consists predominantly of a highly branched $(\mathrm{I}, 3),(\mathrm{I}, 6)$-linked $\beta$-glucan ( $5 \%$ non-reducing end-units, $17 \% 2,4$-di- $O$ methyl-glucose); $\beta(\mathrm{I}, 4)$-linkages (cellulose-type linkages) are in the minority (I $\%$ ). Exolaminaranase was able to dissolve $42 \%$ of the wall material (Table 2 ) giving as products, glucose and gentiobiose (Table 3 ). This indicates the presence of a $(1,3)$-linked $\beta$-D-glucopyranose main-chain, substituted occasionally in the 6-position by very short $\beta$-D-glucopyranose-containing side-chains (Reese \& Mandels, 1963). Another observation supporting this conclusion is that the number of linear $\beta(\mathrm{I}, 6)$-linkages is quite low $(4 \%)$.

The KOH-soluble fraction is a glucan with predominantly $\beta(\mathrm{I}, 3)$-linkages. Exo-laminaranase was able to dissolve $89 \%$ of this glucan with glucose and gentiobiose products. Results of the methylation analysis and the periodate oxidation indicate a branched $(I, 3)-$ linked $\beta$-glucan with each fifth unit substituted in the 6-position. Endo-laminaranase was able to hydrolyse this glucan completely, also indicating long stretches of $(\mathrm{I}, 3)$-linkages (Perlin, 1963). It is possible that the traces of pustulanase and cellulase present in this enzyme preparation stimulate the hydrolysis of this glucan because it also contains $\beta(1,4)-$ and $\beta(I, 6)$-linkages (see Table 4 ).

Electron microscope studies showed that part of the matrix material was dissolved by $\mathrm{KOH}$, while the matrix disappeared completely when the wall was incubated with exolaminaranase (Fig. I $c$ ). This suggests that the matrix material is probably a $(\mathrm{I}, 3)-\beta$-glucan with short $(\mathrm{I}, 6)-\beta$-linked branches. The short fibrils remaining after extensive $(\mathrm{I}, 3)-\beta$ glucanase treatment (Fig. I $e$ ) are not cellulose fibrils but consist of $\beta(\mathrm{I}, 4)-, \beta(\mathrm{I}, 3)$-linked glucans (Table 4). The degree of branching is much lower than that found in the complete wall ( $\mathrm{I}$ in $\mathrm{I} 0$ of every glucose unit is a branching point). This glucan probably still contains long stretches of $\beta(\mathrm{I}, 4)$-linkages because treatment with $\mathrm{H}_{2} \mathrm{O}_{2}$, acetic acid and dilute $\mathrm{HCl}$ gave an X-ray diffraction pattern corresponding to cellulose, it is also sensitive to cellulase and it is extractable with Schweitzer reagent'(Sietsma et al. 1969).

Zevenhuizen \& Bartnicki-Garcia (1969) have shown that the wall of Phytophthora has a similar structure as described above for Pythium. They also assume a covalent link between 


\section{Pythium, hyphal wall composition}

$\beta(\mathrm{I}, 4)$ - and $\beta(\mathrm{I}, 3)$-linked glucans. The hyphal wall of Phytophthora also has two different textures; the internal surface is fibrillar and the outer surface is non-fibrillar (Tokunaga \& Bartnicki-Garcia, I97I). This corresponds to our findings with Pythium. Manocha \& Colvin (I968) present replicas of Pythium walls which have been treated with $\mathrm{HCl}$ and show extreme orientation of the microfibrils. Figures I $c$ and $d$ give some indication of orientation in the microfibrillar texture but the orientation is quite easily destroyed by the manipulation procedures used.

Hyphal walls of most other fungi are of a chitinous nature and contain this substance usually in crystalline condition (Mahadevan \& Tatum, 1967; Troy \& Koffler, 1969). This study and others have shown that cellulose in Oomycete hyphal walls is very poorly crystalline (Cooper \& Aronson, 1967; Manocha \& Colvin, 1968; Tokunaga \& Bartnicki-Garcia, I97I). It also shows that the microfibrils present in the wall are not cellulose fibrils but a mixed $\beta(\mathrm{I}, 3)-, \beta(\mathrm{I}, 4)$-linked glucan.

J. H.S. was Visiting Research ;Officer at the Prairie Regional Laboratory, National Research Council, Saskatoon, Saskatchewan $\mathrm{S}_{7} \mathrm{~N}$ oW9, Canada during 1973. This is N.R.C. publication No. I4I98.

\section{REFERENCES}

Aronson, J. M., CoOPer, B. A. \& Fuller, M. S. (1967). Glucans of Oomycete cell walls. Science, New York I55, 332-335.

AsHWELL, G. (1957). Colorimetric analysis of sugars. In Methods of Enzymology, vol. 3, 4th edn, pp. 73-105. Edited by S. P. Colowick and N. O. Kaplan. New York: Academic Press.

BartNICKI-GaRCiA, S. (1968). Cell wall chemistry, morphogenesis and taxonomy of fungi. Annual Review of Microbiology 22, 87-107.

BJoRndAL, H., LinDBERG, B. \& Svensson, S. (1967). Gas-liquid chromatography of partially methylated alditols as their acetates. Acta chemica scandinavica 21, I80I-1804.

COOPER, B. A. \& ARonson, J. M. (1967). Cell wall structure of Pythium debaryanum. Mycologia 59, 658-670.

Eveleigh, D. E., Sietsma, J. H. \& HASKINS, R. H. (1968). The involvement of cellulase and exo-laminaranase in the formation of Pythium protoplasts. Journal of General Microbiology 52, 89-97.

HAKOMORI, S. (I964). A rapid permethylation of glycolipid, and polysaccharide catalyzed by methyl sulfinyl carbanion in dimethyl sulphoxide. Journal of Biochemistry, Tokyo 55, 205-208.

Hay, G. W., Lewis, B. A. \& SMITH, F. (1965). Periodate oxidation of Polysaccharides. In Methods in Carbohydrate Chemistry, vol. 5, pp. 357-370. Edited by R. L. Whistler and M. L. Wolfrom. New York: Academic Press.

Hirst, E. L. \& Percival, E. (1965). Methylation of polysaccharides and fractionation of the methylated products. In Methods in Carbohydrate Chemistry, vol. 5, pp. 287-296. Edited by R. L. Whistler and M. L. Wolfrom. New York: Academic Press.

Longren, J. \& Pilottr, A. (197I). Gas-liquid chromatography of partially methylated alditols as their acetates. II. Acta chemica scandinavica 25, I144-I 145.

MAHADEVAN, P. R. \& TATUM, E. L. (1967). Localization of structural polymers in the cell wall of Neurospora crassa. Journal of Cell Biology 35, 295-302.

Manocha, M. S. \& Colvin, J. R. (1968). Structure of the cell wall of Pythium debaryanum. Journal of Bacteriology 95, II $40-1$ I 52.

NeLson, N. (1944). A photometric adaptation of the Somogyi method for the determination of glucose. Journal of Biological Chemistry 153, 375-380.

Novaes-Ledieu, M., Jimenez-Martinez, A. \& Villanueva, J. R. (1967). Chemical composition of hyphal walls of Phycomycetes. Journal of General Microbiology 47, 237-245.

PerLIN, A. S. (1963). The action of $\beta$-glycanases and $\beta$-glycans of mixed linkage. In Advances in Enzymatic Hydrolysis of Cellulose and Related Materials, pp. I85-195. Edited by E. T. Reese. New York: Pergamon Press.

PerLIn, A. S. \& TABER, W. A. (1963). A glucan produced by Claviceps purpurea. Canadian Journal of Chemistry 4I, 2278-2282.

ReESE, E. T. \& MANDELS, M. (1963). Enzymatic hydrolysis of $\beta$-glucans. In Advances in Enzymatic Hydrolysis of Cellulose and Related Materials, pp. 187-234. Edited by E. T. Reese. New York: Pergamon Press. 
ReESE, E. T. \& MANDELS, M. (1966). $\beta$-Glucanases other than cellulase. In Methods in Enzymology, vol. 8, 4th edn, pp. 607-615. Edited by S. P. Colowick and N. O. Kaplan. New York: Academic Press.

Sietsma, J. H., Eveleigh, D. E. \& Haskins, R. H. (I968). The purification of cellulase and exo-laminaranase and their role in the formation of Pythium spec. 'protoplasts'. Antonie van Leeuwenhoek 34, 33 I-340.

Sietsma, J. H., Eveleigh, D. E. \& Haskins, R. H. (1969). Cell wall composition and protoplast formation of some Oomycete species. Biochimica et biophysica acta 184, 306-317.

ToKunaga, J. \& BartNicki-Garcia, S. (I97I). Structure and differentiation of the cell wall of Phytophthora palmivora. Archiv für Mikrobiologie 79, 293-310.

Troy, F. A. \& KoffLER, H. (1969). The chemistry and molecular architecture of the cell walls of Penicillium chrysogenum. Journal of Biological Chemistry 244, 5563-5576.

Zevenhuizen, L. P. T. M. \& Bartnicki-Garcia, S. (I969). Chemical structure of the insoluble hyphal wall glucan of Phytophthora cinnamomi. Biochemistry 8, 1496-1502. 